\title{
Anti-corrosive properties of an aqueous extract of Chrysanthemum indicum flower
}

\author{
K. Kavitha, ${ }^{1,2}$ H. Benita sherine ${ }^{2}$ and S. Rajendran ${ }^{3}[0 *$ \\ ${ }^{1} P G$ and Research Department of Chemistry, National College (Autonomous), \\ Tiruchirappalli-620001, Tamil Nadu, India \\ ${ }^{2} P G$ and Research Department of Chemistry, Periyar E.V.R. College (Autonomous), \\ Tiruchirappalli-620023, Tamil Nadu, India \\ ${ }^{3}$ Department of Chemistry, Corrosion Research Centre, St. Antony's College of Arts and \\ Sciences for Women, Dindigul-624005, Tamil Nadu, India \\ *E-mail: susairajendran@gmail.com
}

\begin{abstract}
The anti-corrosive properties of an aqueous extract of Chrysanthemum indicum flower (CIF) in controlling the corrosion of mild steel (MS) in simulated oil well water (SOWW) medium has been evaluated by the weight loss method and by electrochemical measurements. The various functional groups of the CIF was confirmed by Fourier transform infrared spectroscopy (FTIR) analysis. Weight loss method reveals that $10 \mathrm{~mL}$ of an aqueous extract (12\% solution) of CIF offers a maximum corrosion inhibition efficiency of 93\%. Electrochemical methods such as potentiodynamic polarization study and electrochemical impedance spectroscopy were used to study the mechanistic aspects of corrosion inhibition. The Hardness of a metal before and after immersion has been determined. The surface morphology was examined by scanning electron microscopy (SEM) and atomic force microscopy (AFM). The results show that the aqueous extract of CIF acts as a corrosion inhibitor.
\end{abstract}

Keywords: Chrysanthemum indicum flower, corrosion inhibitor, mild steel, simulated oil well water, Vicker hardness, surface morphology.

Received: April 29, 2021. Published: June 10, 2021

doi: $\underline{10.17675 / 2305-6894-2021-10-2-19}$

\section{Introduction}

Corrosion is a dangerous phenomenon due to its negative impacts. The petroleum industry spends huge money annually as lost revenues and maintenance cost which include corrosion prevention [1]. Other economic sectors like manufacturing, transporting, fabrication and construction are also faced with similar dilemma. Therefore, corrosion is a global menace, which requires enhanced solutions. However, one of the reliable ways of curtailing corrosion is by applying inhibitors because they appreciable minimize corrosion rate of materials $[2,3]$. Several literature have exposed that the environmental toxicity of organic and inorganic corrosion inhibitors have encouraged researches to use green corrosion inhibitors, which have economic benefits as they are low cost and biodegradable $[4,5]$. In addition, 
they are ecofriendly, ecologically acceptable and sustainable resource [6]. A large number of green corrosion inhibitors have been studied as an alternative. Therefore, these natural products are becoming the subject of a wider range of investigations.

Most of the effective inhibitors used in industry contain heteroatoms as oxygen (O), phosphorous $(\mathrm{P})$, sulphur $(\mathrm{S})$, nitrogen $(\mathrm{N})$ or aromatic component having multiple bonds leading to an easier adsorption on the metal surface [7, 8]. Several researchers have devoted to corrosion inhibition by plant extracts $[9,10]$, essential oils $[11,12]$ and purified compounds [13], in order to study their properties and the inhibition mechanisms against mild steel corrosion. Many plant extracts such as Sesbaria grandiflora [14], Gleichenia linearis Burm. [15], Urtica dioica [16], Zanthoxylum alatum [17], Vinca rosea [18], etc., have been used against the degradation of material in the aggressive media. Additionally, most of these green products used as corrosion inhibitors are extracted using methanol, ethanol or aqueous solvent. Selvaraj et al. [19] found that Acorus calamus leaves extract obtained by ethanol extraction offered $92 \%$ inhibition efficiency with $0.5 \mathrm{M} \mathrm{HCl}$ at $300 \mathrm{ppm}$. Karthiga et al. [20] have evaluated the inhibitive action of the aqueous extract of $10 \mathrm{~mL}$ of beetroot extract offers 95\% corrosion inhibition efficiency. Saedah and Al-Mhyawi [21] have found that the inhibitive action of the aqueous extract of the Juniperus plant on the mild steel corrosion in an $\mathrm{H}_{2} \mathrm{SO}_{4}$ medium have high inhibition efficiency. Kikanme et al. [22] have found that the inhibitive performance of aqueous Vigna unguiculata coat extract on the corrosion of pipeline steel in $0.5 \mathrm{M} \mathrm{HCl}$ solution. The extract was characterized using GC-MS analysis.

The present research is focused on the effect of the aqueous extract of Chrysanthemum indicum flower (Figure 1) as a corrosion inhibitor for mild steel corrosion in simulated oil well water. Chrysanthemum indicum L. belongs to the family Asteraceae, widely distributed in Asia, mainly in Mongolia, China, Japan and Eastern Europe. Nowadays, most of these plants are cultivated as ornamentals in the whole world [23]. Based on traditional Chinese medicine and Ayurveda, the dried flower heads of Chrysanthemum plants are widely used for the treatment of common cold [24], fever, migraine, conjuctivities, eye irritation, hypertension, inflammation, ulcerative colitis, vertigo, ophthalmia with swelling as well as skin infections [25-27].

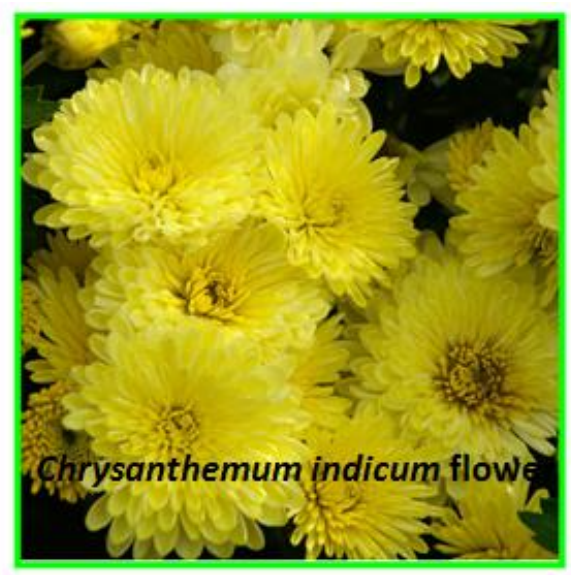

Figure 1. Chrysanthemum indicum flower. 
The aim of the present work is to study the inhibition effect of aqueous extract of Chrysanthemum indicum flower extract as green corrosion inhibitor of mild steel in simulated oil well water. The mechanism of corrosion inhibition of mild steel in simulated oil well water was studied using weight loss method, electrochemical impedance spectroscopy and the potentiodynamic polarization. The morphology of the mild steel surface was examined by FTIR, SEM and AFM.

\section{Experimental}

\section{Preparation of inhibitor}

$12 \mathrm{~g}$ of shade dried Chrysanthemum indicum flower (CIF) was boiled with double distilled water. The extract was filtered and made upto $100 \mathrm{ml}$. This solution was used as corrosion inhibitor.

\section{Preparation of simulated oil well water (SOWW)}

In $100 \mathrm{~mL}$ of DD water, sodium chloride ( $3.5 \mathrm{~g})$, calcium chloride $(0.305 \mathrm{~g})$ and magnesium chloride $(0.186 \mathrm{~g})$ are added. Just before experiment, add $0.067 \mathrm{~g}$ sodium sulfide and $0.4 \mathrm{~mL}$ of concentrated hydrochloric acid to generate hydrogen sulfide gas to form a simulated oil well water containing $100 \mathrm{ppm}$ of $\mathrm{H}_{2} \mathrm{~S}$ [28].

Preparation of mild steel (MS)

Mild steel specimens $(0.0267 \% \mathrm{~S}, 0.06 \% \mathrm{P}, 0.4 \% \mathrm{Mn}, 0.1 \% \mathrm{C}$ and the rest iron) of dimensions $1.0 \mathrm{~cm} \times 4.0 \mathrm{~cm} \times 0.2 \mathrm{~cm}$ were polished to a mirror finish and degreased with acetone.

\section{Weight loss method}

Mild steel specimens in triplicate were immersed in $100 \mathrm{~mL}$ of the simulated oil well water containing various concentrations of the inhibitor (aqueous extract of Chrysanthemum indicum flower) for a period of one day. The weight of the specimens before and after immersion was determined using a Shimadzu balance, model AY62. The corrosion products were cleaned with Clarke's solution [29]. The difference between initial weight prior to deployment and final weight was used for calculation of corrosion rate by using the following formula [30].

\section{Corrosion rate, mdd $=W / A T$}

Where, mdd is corrosion rate expressed in terms of metal loss (mg) per decimeter square area per day, $W$ is loss in weight $(\mathrm{mg}), A$ is area of panels $\left(\mathrm{dm}^{2}\right)$ and $T$ is exposure time (days).

The inhibition efficiency was calculated using the relation.

$$
\text { Inhibition efficiency }=\left[\left(C R_{1}-C R_{2}\right) / C R_{1}\right] \cdot 100 \%
$$


Where, $C R_{1}=$ corrosion rate in the absence of inhibitor, $C R_{2}=$ corrosion rate in the presence of inhibitor.

\section{Electrochemical studies}

In the present work, corrosion resistance of MS immersed in various test solutions were measured by Polarization study and AC impedance spectra. All the experiments were done at room temperature.

\section{Polarization study}

Polarization studies were carried out in a $\mathrm{CHI}$ electrochemical work station with impedance model 660A. It was provided with $i R$ compensation facility. A three electrode cell assembly was used. Mild steel was used as working electrode, platinum as counter electrode and saturated calomel electrode (SCE) as reference electrode. From polarization study, corrosion parameters such as corrosion potential $\left(E_{\text {corr }}\right)$, corrosion current $\left(I_{\text {corr }}\right)$, Tafel slopes anodic $=$ $b_{\mathrm{a}}$ and cathodic $=b_{\mathrm{c}}$ and linear polarization resistance (LPR) value were calculated [31].

\section{AC Impedance spectra}

The same instrument and set-up used for polarization study was used to record AC impedance spectra also. A time interval of 5 to $10 \mathrm{~min}$ was given for the system to attain a steady state open circuit model. The real part $\left(Z^{\prime}\right)$ and imaginary part $\left(-Z^{\prime \prime}\right)$ of the cell impedance were measured in Ohms at various frequencies. AC impedance spectra were recorded with initial $E(\mathrm{~V})=0$, high frequency $\left(1-10^{5} \mathrm{~Hz}\right)$, low frequency $(1 \mathrm{~Hz})$, amplitude $(\mathrm{V})=0.005$ and quiet time $(\mathrm{s})=2$. From Nyquist plot the values of charge transfer resistance $\left(R_{\mathrm{t}}\right)$ and the double layer capacitance $\left(C_{\mathrm{dl}}\right)$ values were calculated. The equivalent circuit diagram (Figure 2) for metal solution interface is presented below [32].

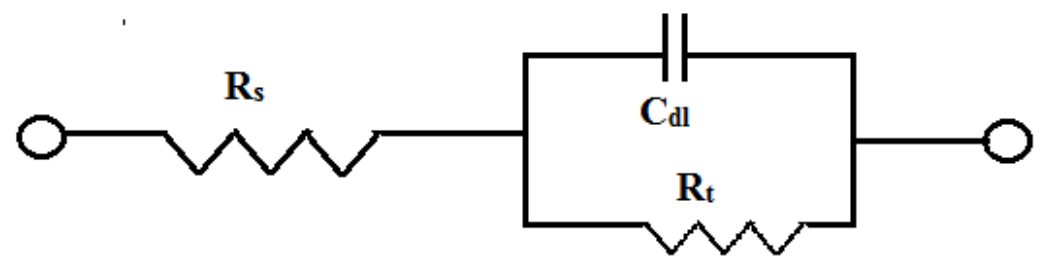

Figure 2. Equivalent circuit diagram.

Where, $C_{\mathrm{dl}}=$ double layer capacitance, $R_{\mathrm{s}}=$ solution resistance, $R_{\mathrm{t}}=$ charge transfer resistance.

FTIR spectra

FTIR spectra were recorded in a Perkin-Elmer "Spectrum Two" spectrophotometer. The film was carefully removed, mixed thoroughly with $\mathrm{KBr}$ made in to pellets and FTIR spectra were recorded. 


\section{Vicker hardness}

The mild steel specimens immersed in various test solutions for one day were taken out, rinsed with double distilled water, dried and subjected to Vicker hardness. The Vicker hardness measurements of the mild steel surface were carried out by Shimadzu make model HMV-2T.

\section{Surface characterization study}

The mild steel specimens were immersed in various test solutions for a period of one day. After one day the specimens were taken out and dried. The nature of the film formed on the metal surface was analyzed by surface characterization studies such as scanning electron microscopy (SEM) and atomic force microscopy (AFM).

\section{Scanning electron microscopy (SEM)}

The mild steel specimens immersed in various test solutions for one day were taken out, rinsed with double distilled water, dried and subjected to the surface examination. The surface morphology measurements of the mild steel surface were carried out by scanning electron microscopy (SEM) using CAREL ZEISS make model EVO-18.

\section{Atomic force microscopy (AFM)}

The mild steel specimens immersed in various test solutions for one day were taken out, rinsed with double distilled water, dried and subjected to the surface examination. The surface morphology measurements of the mild steel surface were carried out by atomic force microscopy (AFM) using SPM Veeco diInnova connected with the software version V7.00 and the scan rate of $0.7 \mathrm{~Hz}$.

\section{Results and Discussion}

A green corrosion of an aqueous extract of Chrysanthemum indicum flower (CIF) has been used to control the corrosion of mild steel in presence of simulated oil well water (SOWW). The findings will be useful in petroleum technology. These inhibitors may be added to oil well water carried by pipelines made of mild steel.

\section{Weight loss method}

Inhibition efficiency (IE\%) and corrosion rate $(C R)$ values calculated from the weight loss method [33] for mild steel with the absence and presence of different concentrations of (CIF) at room temperature are summarized in Table 1. From Table 1, it is evident that as the concentrations of inhibitor increases, inhibition efficiency increases and corrosion rate decreases. The maximum inhibition efficiency of $93 \%$ was attained for mild steel when immersed in $10 \mathrm{~mL}$ of extract concentration. That is oxidation of mild steel is decreased by the coverage of active molecules from the inhibitor on the metal surface. 
Table 1. The corrosion rate and the inhibition efficiency of MS in SOWW medium in different concentrations of inhibitor (CIF).

\begin{tabular}{ccc}
\hline Volume of inhibitor $(\mathbf{C I F}) \mathbf{m L}$ & Corrosion rate $(\boldsymbol{C R}) \mathbf{m d d}$ & $\boldsymbol{I E} \%$ \\
\hline 0 & 14.55 & - \\
2 & 3.64 & 75 \\
4 & 3.26 & 78 \\
6 & 2.76 & 81 \\
8 & 1.75 & 88 \\
10 & 1.02 & 93 \\
\hline
\end{tabular}

\section{Electrochemical study}

Analysis of polarization study

The MS specimen was immersed in SOWW solution containing $10 \mathrm{~mL}$ CIF and CIF-free solution at room temperature. Potentiodynamic polarization measurements were obtained. The curves obtained are presented in Figure 3. Electrochemical parameters such as corrosion potential $\left(E_{\text {corr }}\right)$, Tafel slope $\left(b_{\mathrm{c}}, b_{\mathrm{a}}\right)$, linear polarization resistance $(L P R)$ values and corrosion current $\left(I_{\text {corr }}\right)$ values are given in Table 2 .

It is observed from the Table 2 that when mild steel is immersed in SOWW, the corrosion potential is $-831 \mathrm{mV} v s$ SCE, the $L P R$ value is $501 \mathrm{Ohm} \cdot \mathrm{cm}^{2}$ and corrosion current value is $7.688 \cdot 10^{-5} \mathrm{~A} / \mathrm{cm}^{2}$. It is inferred from the Table 2 that in presence of inhibitor, the corrosion potential is shifted from -831 to $-924 \mathrm{mV}$ vs SCE. In the presence of inhibitor, there is a shift in corrosion potential values when compared with the blank, in which difference is more than $85 \mathrm{mV}$. This proposes that CIF extract behaves predominantly as cathodic inhibitor [34-36]. The LPR value increases (Table 2) from 501 to $786 \mathrm{Ohm} \cdot \mathrm{cm}^{2}$. The corrosion current decreases from $7.688 \cdot 10^{-5}$ to $4.65 \cdot 10^{-5} \mathrm{~A} / \mathrm{cm}^{2}$. These observations confirm that a protective film is formed on the metal surface. This controls the corrosion of metal.

Table 2. Corrosion parameters of MS immersed in SOWW in the absence and presence of inhibitor (CIF) obtained by polarization study.

\begin{tabular}{cccccc}
\hline System & $\begin{array}{c}\boldsymbol{E}_{\text {corr }} \\
\mathbf{m V} \boldsymbol{v} \mathbf{S C E}\end{array}$ & $\begin{array}{c}\boldsymbol{b}_{\mathbf{c}} \\
\mathbf{m V} / \mathbf{d e c a d e}\end{array}$ & $\begin{array}{c}\boldsymbol{b}_{\mathbf{a}} \\
\mathbf{m V} / \mathbf{d e c a d e}\end{array}$ & $\begin{array}{c}\boldsymbol{L P R} \\
\mathbf{O h m} \cdot \mathbf{c m}^{\mathbf{2}}\end{array}$ & $\begin{array}{c}\boldsymbol{I}_{\text {corr }} \\
\mathbf{A} / \mathbf{c m}^{\mathbf{2}}\end{array}$ \\
\hline SOWW & -831 & 150 & 216 & 501 & $7.688 \cdot 10^{-5}$ \\
\hline $\begin{array}{c}\text { SOWW }+ \\
10 \mathrm{~mL} \mathrm{CIF}\end{array}$ & -924 & 138 & 216 & 786 & $4.654 \cdot 10^{-5}$ \\
\hline
\end{tabular}




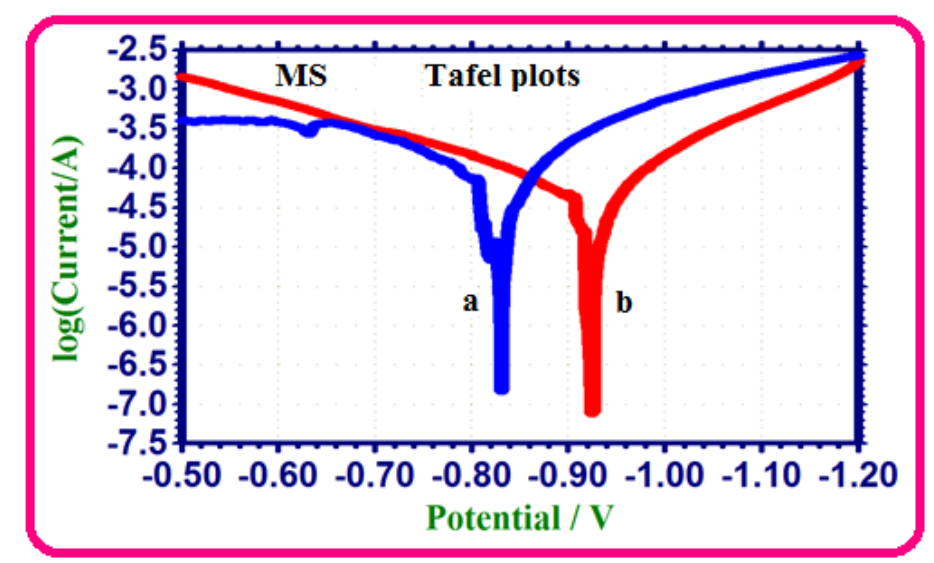

Figure 3. Polarization curves of mild steel immersed in various test solutions (a) SOWW, (b) SOWW + inhibitor (CIF).

\section{Analysis of AC impedance spectra}

AC impedance spectra (electrochemical impedance spectra) have been used to confirm the formation of protective film on the metal surface [37-39]. If a protective film is formed on the metal surface, charge transfer resistance $\left(R_{\mathrm{t}}\right)$ increases, double layer capacitance value $\left(C_{\mathrm{dl}}\right)$ decreases and impedance $[\log (Z / \mathrm{Ohm})]$ value increases. The phase angle value increases. The AC impedance spectra of mild steel immersed in SOWW in presence and absence of inhibitor (CIF) are shown in Figure 4 (Nyquist plot) Figure 5 (a, b) (Bode plots).

The AC impedance parameters namely charge transfer resistance $\left(R_{\mathrm{t}}\right)$ and double layer capacitance derived from Nyquist plots are given in Table 3. The impedance values derived from Bode plots are also given in Table 3. It is observed that when the inhibitor (CIF) is added, the charge transfer resistance value increases from $15.96 \mathrm{Ohm} \cdot \mathrm{cm}^{2}$ to $40.63 \mathrm{Ohm} \cdot \mathrm{cm}^{2}$. The $C_{\mathrm{dl}}$ value decreases from $3.194 \cdot 10^{-7} \mathrm{~F} / \mathrm{cm}^{2}$ to $1.255 \cdot 10^{-7} \mathrm{~F} / \mathrm{cm}^{2}$. The impedance value increases from 1.403 to 1.755 . The phase angle value increases from 23.00 to 29.58 . These results lead to the conclusion that a protective film is formed on the metal surface.

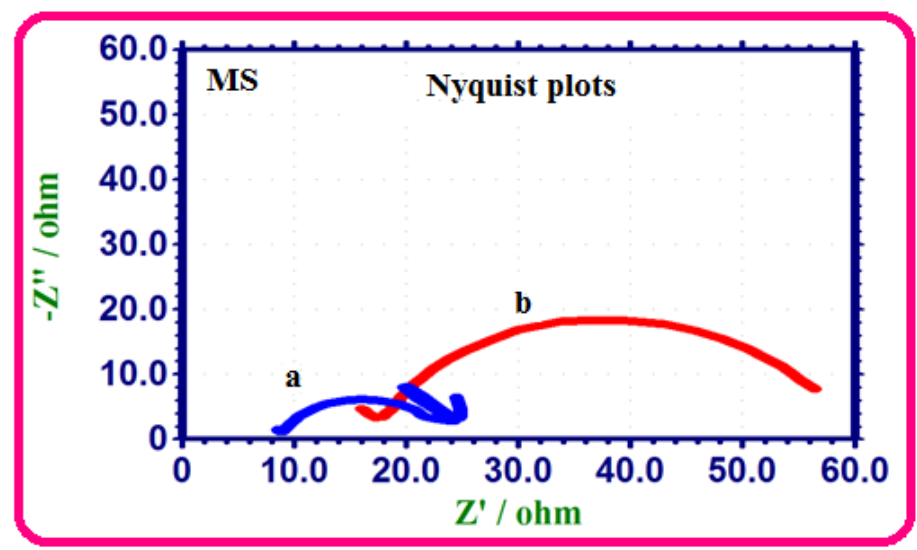

Figure 4. AC impedance spectra of mild steel immersed in various test solutions (Nyquist plot): (a) SOWW; (b) SOWW + inhibitor (CIF). 


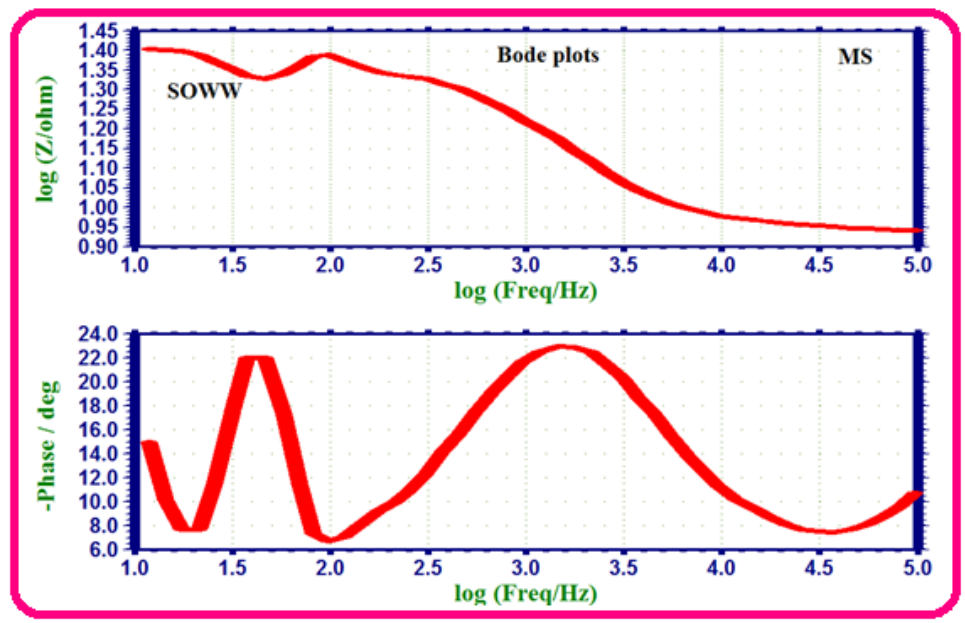

Figure 5a. AC impedance spectra of mild steel immersed in SOWW (Bode plots).

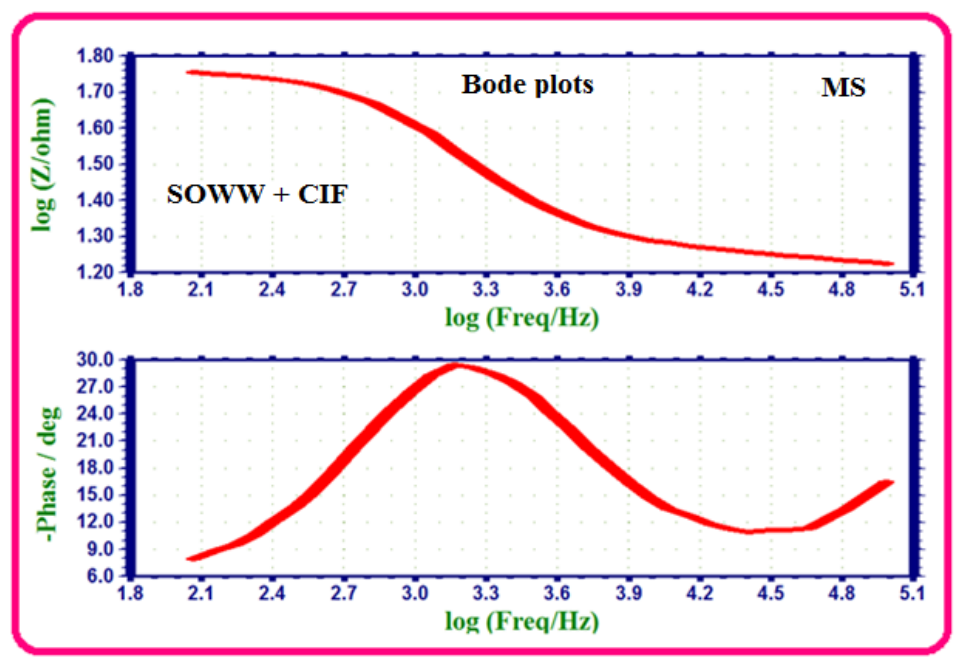

Figure 5b. AC impedance spectra of mild steel immersed in SOWW + Inhibitor (CIF) (Bode plots).

Table 3. Corrosion parameters of mild steel (MS) immersed in SOWW in the absence and presence of inhibitor (CIF) obtained by the impedance spectra.

\begin{tabular}{ccccc}
\hline \multirow{2}{*}{ System } & \multicolumn{2}{c}{ Nyquist plot } & \multicolumn{2}{c}{ Bode plot } \\
\cline { 2 - 5 } & $\begin{array}{c}\boldsymbol{R}_{\mathbf{t}} \\
\text { Ohm } \cdot \mathbf{c m}^{2}\end{array}$ & $\begin{array}{c}\boldsymbol{C}_{\mathbf{d l}} \\
\mathbf{F} / \mathbf{c m}^{2}\end{array}$ & $\begin{array}{c}\text { Impedance } \\
{[\mathbf{L o g}(\boldsymbol{Z} / \mathbf{O h m})]}\end{array}$ & $\begin{array}{c}\text { Phase angle } \\
(\mathbf{d e g r e e s})\end{array}$ \\
\hline SOWW & 15.96 & $3.194 \cdot 10^{-7}$ & 1.403 & 23.00 \\
\hline $\begin{array}{c}\text { SOWW }+ \\
10 \mathrm{~mL} \mathrm{CIF}\end{array}$ & 40.63 & $1.255 \cdot 10^{-7}$ & 1.755 & 29.58 \\
\hline
\end{tabular}




\section{FTIR spectra}

FTIR spectra have been used in corrosion inhibition study to analyze the protective film formed on the metal surface. A few drops of an aqueous extract of Chrysanthemum indicum flower were dried on a glass plate. A solid mass was obtained. The FTIR spectrum (Figure 6) of CIF extract shows characteristic peak to $\mathrm{O}-\mathrm{H}$ stretching frequency appears at $3430.78 \mathrm{~cm}^{-1}$. $\mathrm{C}-\mathrm{H}$ stretching frequency appears at $2929.37 \mathrm{~cm}^{-1}$. The peak at $1628.51 \mathrm{~cm}^{-1}$ corresponds to $\mathrm{C}=\mathrm{O}$ stretching frequency of carbonyl group. The peak at $1409.91 \mathrm{~cm}^{-1}$ corresponds to $\mathrm{C}=\mathrm{C}$ (aromatic ring) stretching frequency and $\mathrm{C}-\mathrm{H}$ bending. The peaks at $1259.80 \mathrm{~cm}^{-1}$ and $1073.41 \mathrm{~cm}^{-1}$ correspond to $\mathrm{C}-\mathrm{O}$ stretching frequency. FTIR data indicate the presence of functional groups present in the aqueous extract of CIF.

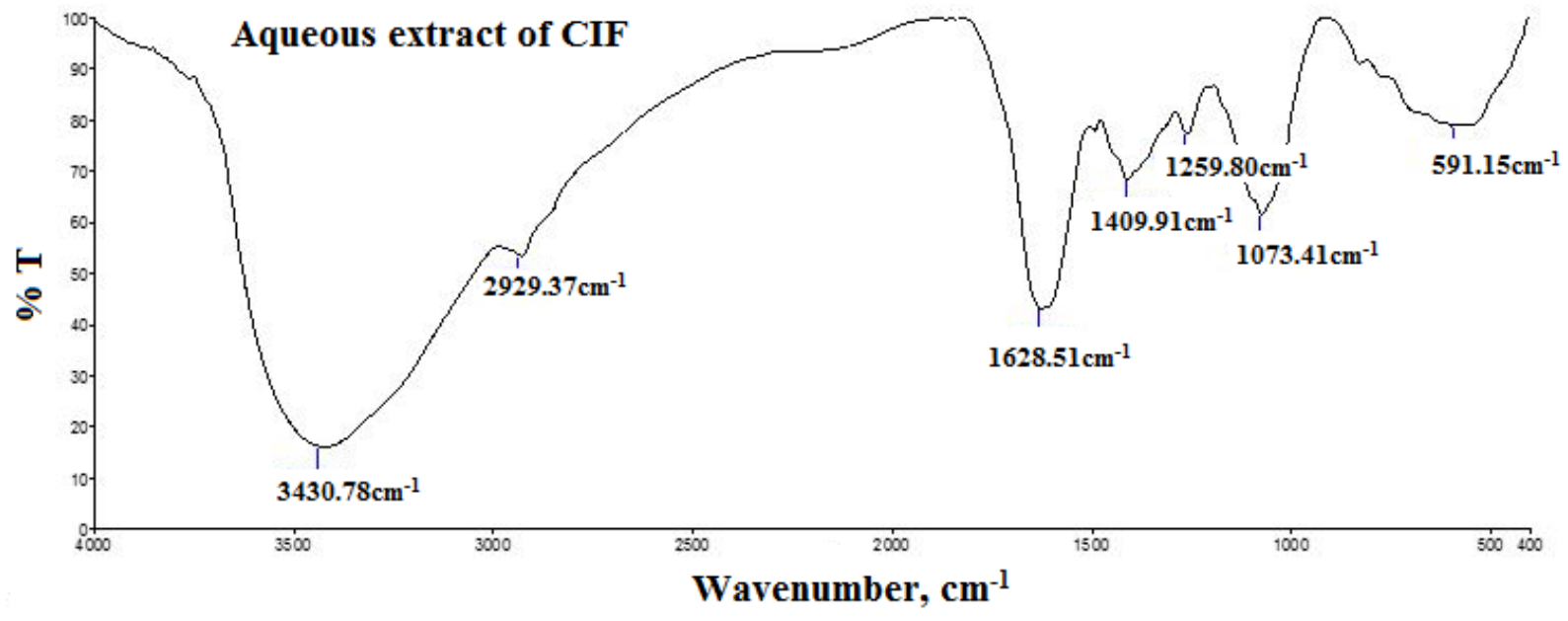

Figure 6. FTIR spectrum of pure aqueous extract of CIF evaporated to dryness.

The FTIR spectrum of the protective film formed on the surface of the metal after immersion in the SOWW containing inhibitor CIF has shown in Figure 7. It is found that $\mathrm{O}-\mathrm{H}$ stretching frequency has shifted from $3430.78 \mathrm{~cm}^{-1}$ to $3428.70 \mathrm{~cm}^{-1}, \mathrm{C}-\mathrm{H}$ stretching frequency was disappeared, while $\mathrm{C}=\mathrm{O}$ stretching frequency has shifted from $1628.51 \mathrm{~cm}^{-1}$ to $1629.94 \mathrm{~cm}^{-1}$. The $\mathrm{C}=\mathrm{C}$ stretching frequency has shifted from $1409.91 \mathrm{~cm}^{-1}$ to $1382.95 \mathrm{~cm}^{-1}$. The $\mathrm{C}-\mathrm{O}$ stretching has shifted from $1259.80 \mathrm{~cm}^{-1}$ and $1073.41 \mathrm{~cm}^{-1}$ to $1119.65 \mathrm{~cm}^{-1}$ and $1021.78 \mathrm{~cm}^{-1}$ respectively (Table 4). The peak at $693.26 \mathrm{~cm}^{-1}$ is due to metal-oxygen bond. The FTIR spectral study leads to the conclusion that the protective film consists of $\mathrm{Fe}^{2+}$-CIF complex [40, 41]. 


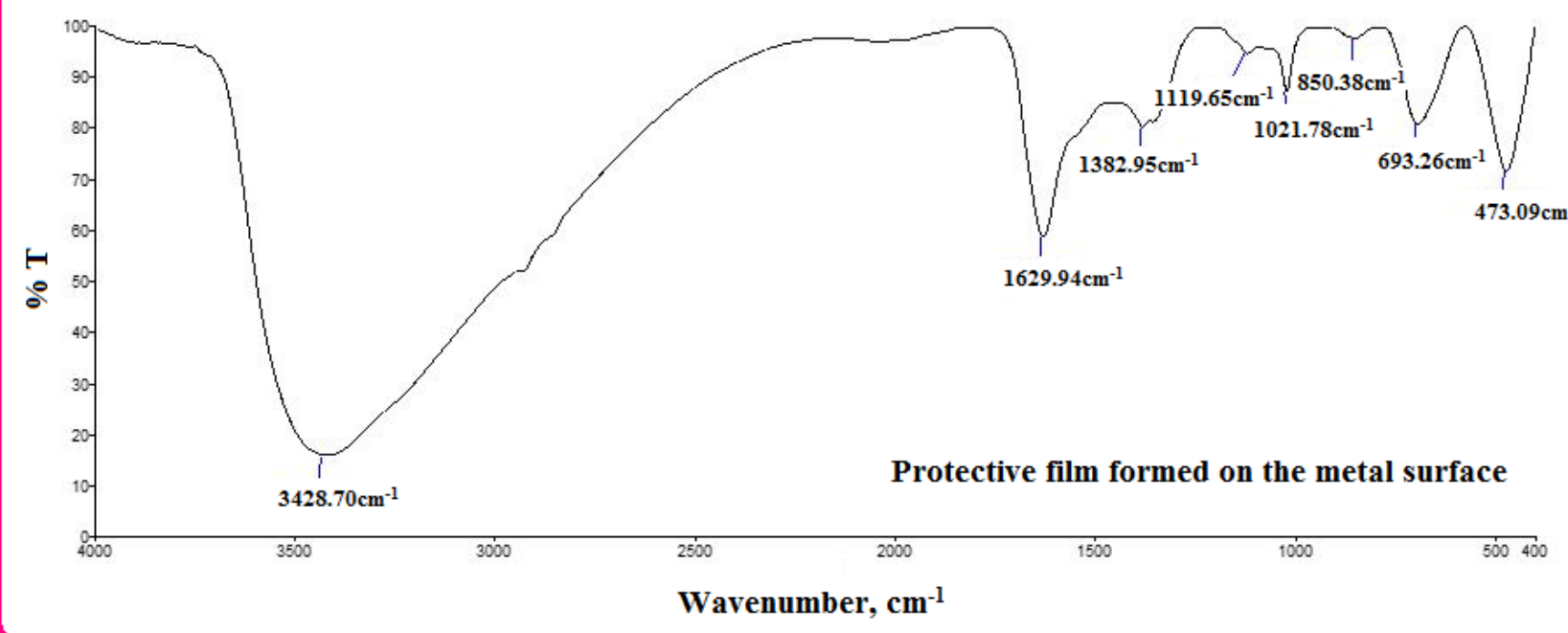

Figure 7. FTIR spectrum of protective film formed on the mild steel surface during the immersion in SOWW containing inhibitor (CIF).

Table 4. The stretching frequency of various functional groups.

\begin{tabular}{ccc}
\hline \multirow{2}{*}{ Functional groups } & \multicolumn{2}{c}{ Stretching frequency, $\mathrm{cm}^{-1}$} \\
\cline { 2 - 3 } & Extract $(\mathrm{CIF})$ & Protective film \\
\hline OH stretching & 3430.78 & 3428.70 \\
\hline $\mathrm{C}-\mathrm{H}$ stretching & 2929.37 & - \\
\hline $\mathrm{C}=\mathrm{O}$ stretching & 1628.51 & 1629.94 \\
\hline $\mathrm{C}=\mathrm{C}$ (aromatic ring) stretching \\
and C-H bending
\end{tabular}

\section{Analysis of SEM}

The SEM images of various surfaces are shown in Figure 8. The SEM image of polished mild steel is shown in Figure 8(a). The SEM image of polished mild steel immersed in SOWW is shown in Figure 8(b). The SEM image of the polished mild steel immersed in SOWW and inhibitor (CIF) system is shown in Figure 8(c). The SEM image of polished mild steel is smooth. The SEM image of the mild steel in SOWW is found to be rough and the pits are visible on the mild steel surface. The SEM image of the mild steel in SOWW and inhibitor (CIF) system is smooth due to the formation of protective film. Thus SEM study is useful to know the smoothness of the protective film [42-44]. 


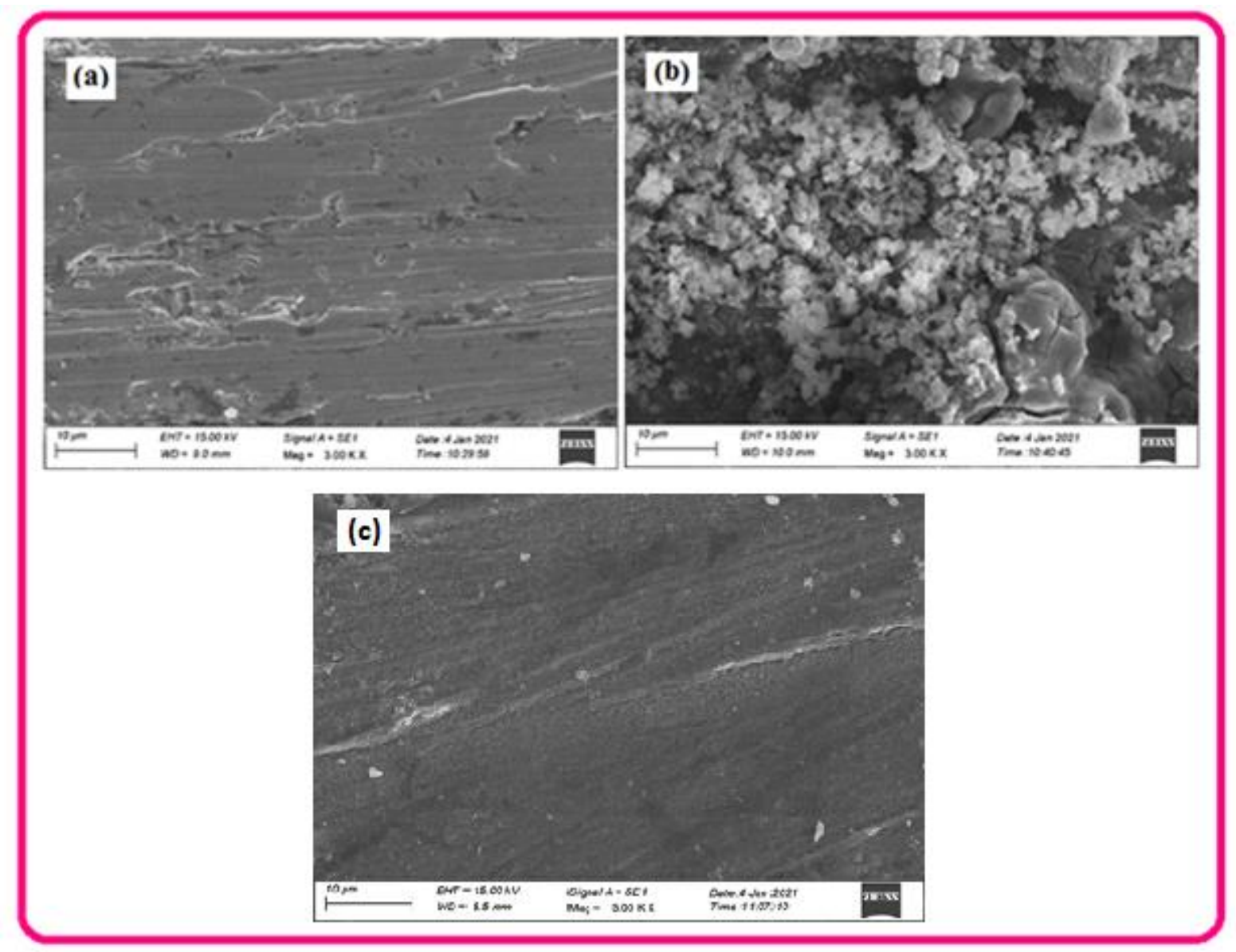

Figure 8. SEM images of (a) Polished mild steel (b) mild steel immersed in SOWW (c) mild steel immersed in SOWW containing inhibitor (CIF).

\section{Analysis of Vicker hardness}

The Vicker hardness was measured for polished mild steel surface (system A), polished mild steel immersed in corrosive medium (SOWW) (system B) and polished mild steel surface immersed in corrosive medium (SOWW) containing the inhibitor (CIF) (system C). The values are given in Table 5.

The Vicker hardness was measured for $25 \mathrm{~g}$ load and $50 \mathrm{~g}$ load at two places each. It is observed that for system A the hardness is high. For system B the hardness is low because the corroded surface contains iron oxide film which is porous and amorphous surface is very rough. Pits are noticed due to corrosion. For system $\mathrm{C}$ the surface is smooth, due to the formation of protective film. The hardness is in between that of system A and B. That is lower than that of polished metal but higher than that of corroded surface. The average hardness values are given in Table 6 and 7. Thus the Vicker hardness is used in corrosion inhibition study [45]. 
Table 5. Vicker Hardness (HV) of various surfaces measured along L1 and L2.

\begin{tabular}{lccccc}
\hline System & Load & S. No. & L1 & L2 & HV \\
\hline Polished metal & $25 \mathrm{~g}$ & 1 & 29.27 & 30.04 & 52.7 \\
Polished metal & $25 \mathrm{~g}$ & 2 & 29.00 & 29.64 & 52.9 \\
Polished metal & $50 \mathrm{~g}$ & 1 & 35.50 & 36.10 & 72.7 \\
Polished metal & $50 \mathrm{~g}$ & 2 & 35.14 & 36.02 & 73.2 \\
Corroded metal & $25 \mathrm{~g}$ & 1 & 44.70 & 47.01 & 22.0 \\
Corroded metal & $25 \mathrm{~g}$ & 2 & 44.71 & 46.12 & 22.5 \\
Corroded metal & $50 \mathrm{~g}$ & 1 & 49.41 & 51.79 & 36.2 \\
Corroded metal & $50 \mathrm{~g}$ & 2 & 50.35 & 52.03 & 35.3 \\
Inhibited metal & $25 \mathrm{~g}$ & 1 & 33.71 & 35.82 & 38.3 \\
Inhibited metal & $25 \mathrm{~g}$ & 2 & 33.02 & 34.30 & 40.9 \\
Inhibited metal & $50 \mathrm{~g}$ & 1 & 36.05 & 37.93 & 67.7 \\
Inhibited metal & $50 \mathrm{~g}$ & 2 & 36.16 & 37.32 & 68.6 \\
\hline
\end{tabular}

Table 6. HV (average) for $25 \mathrm{~g}$ load.

\begin{tabular}{cc}
\hline System & HV, average \\
\hline Polished metal & 52.8 \\
Corroded metal SOWW & 22.25 \\
Inhibited metal CIF extract & 39.6 \\
\hline
\end{tabular}

Table 7. HV (average) for $50 \mathrm{~g}$ load.

\begin{tabular}{cc}
\hline System & HV, average \\
\hline Polished metal & 72.95 \\
Corroded metal SOWW & 35.75 \\
Inhibited metal CIF extract & 68.15 \\
\hline
\end{tabular}

\section{Atomic Force Microscopic Studies}

The two dimensional AFM images of polished metal surface, corroded surface (immersed in SOWW) and the film protected metal (SOWW + inhibitor CIF solution) are shown in Figure 9a, Figure $9 \mathrm{~b}$ and Figure 9c. The corresponding three dimensional images are shown in Figure 10a, Figure 10b and Figure 10c. The AFM parameters RMS $\left(R_{\mathrm{q}}\right)$ roughness $(\mathrm{nm})$, Average $\left(R_{\mathrm{a}}\right)$ roughness $(\mathrm{nm})$ and maximum peak-to-valley height $(\mathrm{nm})$ were calculated. 
These values are given in Table 8, for polished mild steel, mild steel immersed in SOWW and mild steel immersed in inhibitor system.

It is observed from the Table 8 that the RMS roughness of polished mild steel is $116.89 \mathrm{~nm}$. The average roughness is $98.65 \mathrm{~nm}$. The maximum peak-to-valley height is $477.84 \mathrm{~nm}$. Analysis of Table 8 reveals that the RMS roughness value of mild steel immersed in SOWW is higher than that of the polished mild steel. This is due to corrosion. Thick nano film is formed on the metal surface. Similar is the case of average roughness and maximum peak-to-valley height. For the metal immersed in inhibitor system, the RMS roughness is less than that of the metal immersed in corrosive medium. Similar is the case in the case of average roughness and maximum-peak-to-valley height. This indicates that a protective film of nano scale is formed on the metal surface. This film protects the metal from corrosion [46].

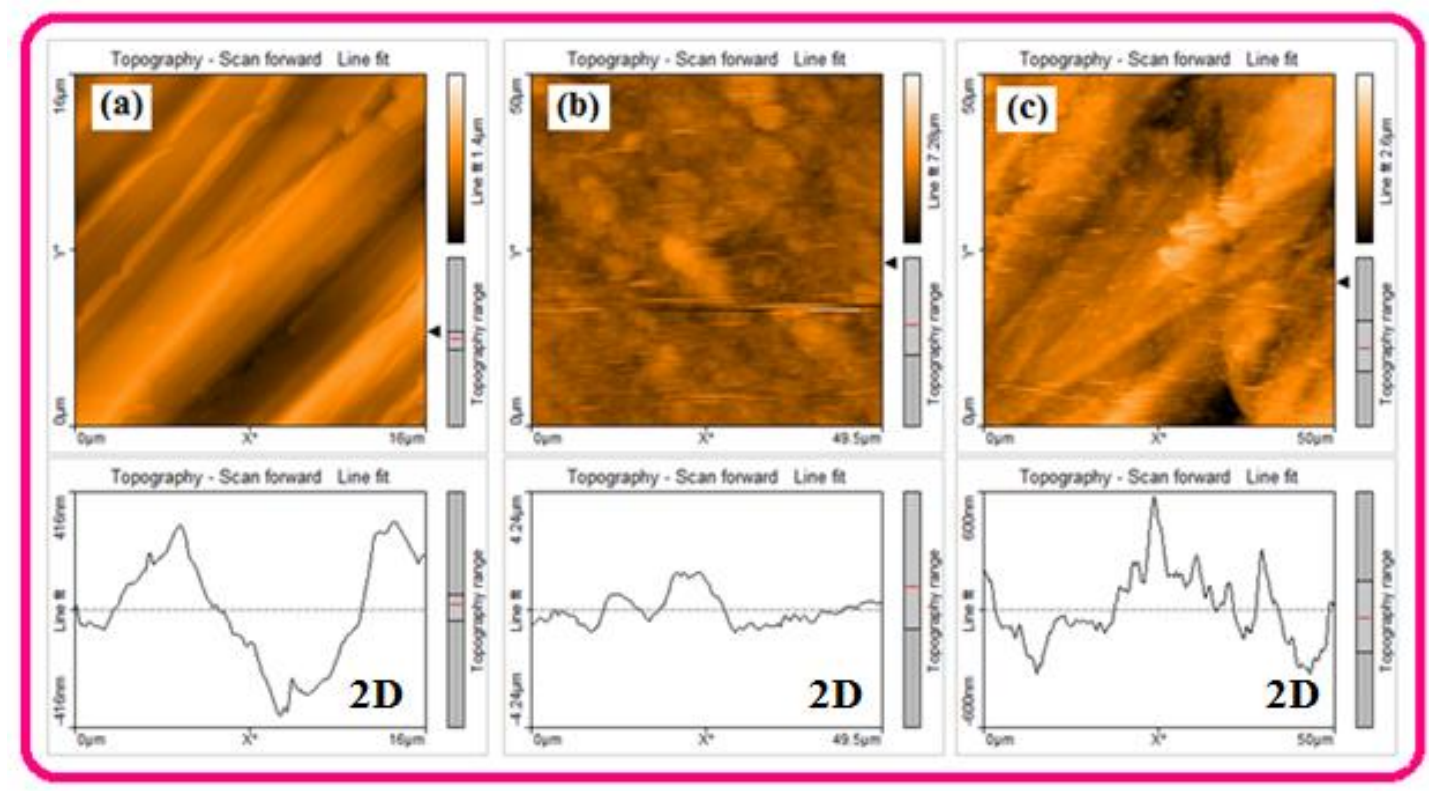

Figure 9. (a,b,c) Two dimensional AFM images (a) polished MS; (b) MS immersed in SOWW; (c) MS immersed in SOWW containing inhibitor (CIF) system.

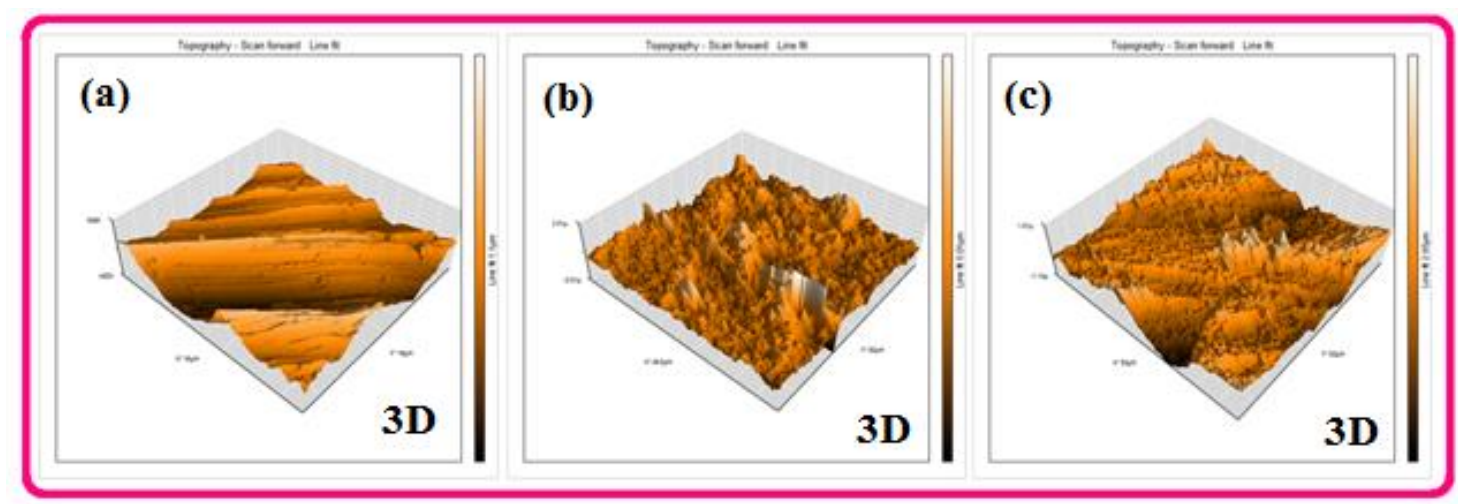

Figure 10. (a,b,c) Three dimensional AFM images of the surface (a) polished MS; (b) MS immersed in SOWW; (c) MS immersed in SOWW containing inhibitor (CIF) system. 
Table 8. AFM parameters of mild steel surface in the presence and absence of inhibitor (CIF) system.

\begin{tabular}{cccc}
\hline Sample & $\begin{array}{c}\text { RMS }\left(\boldsymbol{R}_{\mathbf{q}}\right) \text { Roughness } \\
(\mathbf{n m})\end{array}$ & $\begin{array}{c}\text { Average }\left(\boldsymbol{R}_{\mathbf{a}}\right) \\
\text { Roughness }(\mathbf{n m})\end{array}$ & $\begin{array}{c}\text { Maximum peak-to- } \\
\text { valley height }(\mathbf{n m})\end{array}$ \\
\hline Polished MS & 116.89 & 98.65 & 477.84 \\
\hline $\begin{array}{c}\text { MS immersed in } \\
\text { SOWW }\end{array}$ & 623.84 & 456.15 & 2901.5 \\
\hline $\begin{array}{c}\text { MS immersed in } \\
\text { SOWW and 10 mL of } \\
\text { CIF extract }\end{array}$ & 302.85 & 221.82 & 1255.2 \\
\hline
\end{tabular}

\section{Conclusions}

- In this study, the anti-corrosive properties of an aqueous extract of CIF have been tested against the mild steel in SOWW medium.

- The presence of phenolic group $\mathrm{O}-\mathrm{H}$, carbonyl group $\mathrm{C}=\mathrm{O}$, unsaturated group $\mathrm{C}=\mathrm{C}, \mathrm{C}-$ $\mathrm{O}$ group and $\mathrm{C}-\mathrm{H}$ group containing compounds with heteroatom has been identified in the aqueous extract of CIF.

- Decrease in corrosion rate and increase in inhibition efficiency of mild steel in SOWW media was observed with the increase in concentration of CIF. The maximum inhibition efficiency of $93 \%$ was achieved for $10 \mathrm{~mL}$ of CIF.

- The potentiodynamic polarization studies conclude that CIF performed as a cathodic type of inhibitor.

- According to electrochemical impedance spectroscopy, there was an increase in polarization resistance $\left(R_{\mathrm{t}}\right)$ and decrease in double layer capacitance $\left(C_{\mathrm{dl}}\right)$. This behavior was found to be due to the formation of dense protective layer on the metal surface.

- The hardness of the metal surface containing the protective film is in between that of polished metal and that of the corroded metal in SOWW.

- Furthermore, microscopic studies including SEM and AFM have indicated the presence of smooth surface in case of inhibited mild steel when compared to the uninhibited samples.

- The investigated aqueous extract of CIF acted as an efficient corrosive inhibitor of mild steel in SOWW medium.

\section{References}

1. L.T. Popoola, A.S. Grema, G.K. Latinwo, B. Gutti and A.S. Balogun, Corrosion problems during oil and gas production and its mitigation, Int. J. Ind. Chem., 2013, 4, no. 1, 35. doi: $10.1186 / 2228-5547-4-35$

2. A.S. Fouda, A. Emam, R. Refat and M. Nageeb, Cascabela Thevetia Plant Extract as Corrosion Inhibitor for Carbon Steel in Polluted Sodium Chloride Solution, J. Anal. Pharm. Res., 2017, 6, no. 1, 00168. doi: 10.15406/japlr.2017.06.00168 
3. O.K. Abiola, Adsorption of 3-(4-amino-2-methyl-5-pyrimidyl methyl)-4-methyl thiazolium chloride on mild steel, Corros. Sci., 2006, 48, 3078-3090. doi: 10.1016/j.corsci.2005.12.001

4. R. Souli, E. Triki, M. Rezrazi, P. Berçot, M. Rezrazi, B. Jaouad, A. Derja and L. Dhouibi, Nigella sativa: an alternative solution for the corrosion of mild steel in hydrochloric acid medium, J. Mater. Environ. Sci., 2015, 6, 2729-2735.

5. J. Halambek, K. Berković and J. Vorkapić-Furač, Laurus nobilis L. oil as green corrosion inhibitor for aluminium and AA5754 aluminium alloy in 3\% $\mathrm{NaCl}$ solution, Mater. Chem. Phys., 2013, 137, 788-795. doi: 10.1016/j.matchemphys.2012.09.066

6. K. Boumhara, M. Tabyaoui, C. Jama and F. Bentiss, Artemisia Mesatlantica essential oil as green inhibitor for carbon steel corrosion in $1 \mathrm{M} \mathrm{HCl}$ solution: Electrochemical and XPS investigations6 J. Ind. Eng. Chem., 2015, 29, 146-155. doi: 10.1016/j.jiec.2015.03.028

7. R. Solmaz, Investigation of the inhibition effect of 5-((E)-4-phenylbuta-1,3dienylideneamino)-1,3,4-thiadiazole-2-thiol Schiff base on mild steel corrosion in hydrochloric acid, Corros. Sci., 2010, 52, 3321-3330. doi:10.1016/j.corsci.2010.06.001

8. A. Singh, E.E. Ebenso and M.A. Quraishi, Corrosion Inhibition of Carbon Steel in $\mathrm{HCl}$ Solution by Some Plant Extracts, Int. J. Corros., 2012, 897430. doi: $10.1155 / 2012 / 897430$

9. P. Bothi Raja and M.G. Sethuraman, Inhibitive effect of black pepper extract on the sulphuric acid corrosion of mild steel, Mater. Lett., 2008, 62, 2977-2979. doi: 10.1016/j.matlet.2008.01.087

10. R. Idouhli, A. Abouelfida, A. Benyaich and A. Aityoub, Cuminum Cyminum Extract- A Green Corrosion Inhibitor of S300 Steel in $1 \mathrm{M} \mathrm{HCl}$, Chem. Process Eng. Res., 2016, 44, 16-25.

11. M. Znini, L. Majidi, A. Bouyanzer, J. Paolini, J.-M. Desjobert, J. Costa and B. Hammouti, Essential oil of Salvia aucheri mesatlantica as a green inhibitor for the corrosion of steel in $0.5 \mathrm{M} \mathrm{H}_{2} \mathrm{SO}_{4}$, Arabian J. Chem., 2012, 5, 467-474. doi: 10.1016/j.arabjc.2010.09.017

12. R. Idouhli, A. Oukhrib, Y. Koumya, A. Abouelfida, A. Benyaich and A. Benharref, Inhibitory effect of Atlas cedar essential oil on the corrosion of steel in $1 \mathrm{~m} \mathrm{HCl}$, Corros. Rev., 2018, 36, 373-384. doi: 10.1515/corrrev-2017-0076

13. C.B. Verma, M.A. Quraishi and A. Singh, 2-Aminobenzene-1,3-dicarbonitriles as green corrosion inhibitor for mild steel in $1 \mathrm{M} \mathrm{HCl}$ : Electrochemical, thermodynamic, surface and quantum chemical investigation, J. Taiwan Inst. Chem. Eng., 2015, 49, 229-239. doi: $\underline{10.1016 / j . j t i c e .2014 .11 .029}$

14. A. Krishnan and S.M.A. Shibli, Optimization of an efficient, economic and eco-friendly inhibitor based on Sesbania grandiflora leaf extract for the mild steel corrosion in aggressive $\mathrm{HCl}$ environment, Anti-Corros. Methods Mater., 2018, 65, 210-216. doi: 10.1108/ACMM-06-2017-1810 
15. Y. Stiadi, M. Efdi, H. Aziz and Emriadi, Gleichenia linearis Burm. Leaf extract as corrosion inhibitor of mild steel in hydrochloric acid medium, Int. J. Corros. Scale Inhib., 2020, 9, no. 4, 1498-1515. doi: 10.17675/2305-6894-2020-9-4-20

16. E. Salehi, R. Naderi and B. Ramezanzadeh, Synthesis and characterization of an effective organic/inorganic hybrid green corrosion inhibitive complex based on zinc acetate/Urtica Dioica, Appl. Surf. Sci., 2017, 396, 1499-1514. doi: 10.1016/j.apsusc.2016.11.198

17. L.R. Chauhan and G. Gunasekaran, Corrosion inhibition of mild steel by plant extract in dilute $\mathrm{HCl}$ medium, Corros. Sci., 2007, 49, 1143-1161. doi: 10.1016/j.corsci.2006.08.012

18. J. Arockia Selvi, M. Arthanareeswari, T. Pushpamalini, S. Rajendran and T. Vignesh, Effectiveness of Vinca rosea leaf extract as corrosion inhibitor for mild steel in $1 \mathrm{~N} \mathrm{HCl}$ medium investigated by adsorption and electrochemical studies, Int. J. Corros. Scale Inhib., 2020, 9, no. 4, 1429-1443. doi: 10.17675/2305-6894-2020-9-4-15

19. S.K. Selvaraj, M. Ganga Gowri, J. Deepika, K. Karthik Kumar and A. John Amalraj, Int. J. Nano Corr. Sci. Engg., 2017, 4, 4.

20. N. Karthiga，S. Rajendran, P. Shanthy，A. Krishnaveni，J. Jeyasundari， R.M. Joany, A. Christy Catherine Mary and T. Umasankareswari, Int. J. Nano Corr. Sci. Engg., 2015,2 , no. 5, 255-269.

21. S.R. Al-Mhyawi, Inhibition of mild steel corrosion using Juniperus plants as green inhibitior, Afr. J. Pure Appl. Chem., 2014, 8, no. 1, 9-22. doi: 10.5897/AJPAC2013.0497

22. N.K. Kikanme, A.O. James and N.C. Ngobiri, Vigna unguiculata Coat Extract as Green Corrosion Inhibitor for Steel Pipeline in HCl, J. Mater. Sci. Res. Rev., 2020, 5, no. 1, 7 20.

23. D.J. Mabberley, Mabberley's Plant-Book: A Portable Dictionary of Plants, Cambridge University Press: New York, NY, USA, 2008, 1021. doi: $10.1002 /$ fedr.19981090507

24. M.H. Shahrajabian, A review of chrysanthemum, the eastern queen in traditional chinese medicine with healing power in modern pharmaceutical sciences, Appl. Ecol. Environ. Res., 2019, 17, 13355-13369. doi: 10.15666/aeer/1706_1335513369

25. C. Wiart, Ethnopharmacology of Medicinal Plants: Asia and the Pacific, Humana Press: Totowa, NJ, USA, 2006, 12, 228.

26. C.P. Khare, Indian Medicinal Plants: An Illustrated Dictionary, Springer Reference, Springer: Berlin, Germany, 2007, 10, 32.

27. B.-E. Van Wyk and M. Wink, Medicinal Plants of the World: An Illustrated Scientific Guideto Important Medicinal Plants and Their Uses, 1st ed.; Timber Press: Portland, OR, USA, 2004, 480.

28. R. Geethanjali and S. Subhashini, Investigation of Corrosion Inhibition Efficiency of Some Synthesized Water Soluble Terpolymers on N-80 Steel in $\mathrm{HCl}, \mathrm{NaCl}$ and Simulated Oil Well Water, Port. Electrochim. Acta, 2015, 33, no. 2, 85-104. doi: $\underline{10.4152 / \text { pea.201502085 }}$ 
29. G. Wranglen, Introduction to Corrosion and Protection of Metals, London: Chapman and Hall, 1986, 236.

30. S.S. Sawant, D. Khandeparker, A. Tulaskar, K. Venkat and A. Garg, Corrosion and microfouling of copper and its alloys in a tropical marine waters of India (Mangalore), Indian J. Chem. Technol., 1995, 2, 322-326.

31. S. Rajendran, R.J. Rathish and S.S. Prabha, Self-assembling nano films on metal surface as corrosion inhibitors, Adv. Mater. Proc., 2017, 2, no. 9, 596-601. doi: 10.5185/amp.2017/650

32. A.A. Aghzzaf, D. Veys-Renaux and E. Rocca, Mater. Corros., Pomegranate peels crude extract as a corrosion inhibitor of mild steel in $\mathrm{HCl}$ medium: Passivation and hydrophobic effect, 2020, 71, no. 1, 148-154. doi: $10.1002 /$ maco.201911049

33. P.N. Devi, J. Sathiyabama and S. Rajendran, Study of surface morphology and inhibition efficiency of mild steel in simulated concrete pore solution by lactic acid- $\mathrm{Zn}^{2+}$ system, Int. J. Corros. Scale Inhib., 2017, 6, no. 1, 18-31. doi: 10.17675/2305-6894-2017-6-1$\underline{2}$

34. P.O. Ameh, A.M. Kolo, A. Ahmed and I.K. Ajanaku, J. Ind. Environ. Chem., 2017, 1, no. 1, 57-66.

35. E.E. Oguzie, Corrosion inhibition of aluminium in acidic and alkaline media by Sansevieria trifasciata extract, Corros. Sci., 2007, 49, no. 3, 1527-1539. doi: 10.1016/j.corsci.2006.08.009

36. H. Gerengi, I. Uygur, M. Solomon, M. Yildiz and H. Goksu, Evaluation of the inhibitive effect of Diospyros kaki (Persimmon) leaves extract on St37 steel corrosion in acid medium, Sustainable Chem. Pharm., 2016, 4, 57-66. doi: 10.1016/j.scp.2016.10.003

37. S. Zhang, Z. Tao, W. Li and B. Hou, The effect of some triazole derivatives as inhibitors for the corrosion of mild steel in $1 \mathrm{M}$ hydrochloric acid, Appl. Surf. Sci., 2009, 255, 6757-6763. doi: 10.1016/j.apsusc.2008.09.089

38. F. El-Taib Heakal, A.S. Fouda and M.S. Radwan, Inhibitive effect of some thiadiazole derivatives on C-steel corrosion in neutral sodium chloride solution, Mater. Chem. Phys., 2011, 125, 26-36. doi: 10.1016/j.matchemphys.2010.08.067

39. S. Rajendran, M.K. Devi, A.P.P. Regis, A.J. Amalraj, J. Jeyasundari and M. Manivannan, Electroplating using environmental friendly garlic extract - A case study, Zastita Materijala, 2009, 50, 131-140.

40. P.O. Ameh, A.M. Kolo, A. Ahmed and I.K. Ajanaku, Electrochemical study of the corrosion inhibition of Delonix regia for mild steel in sulphuric acid medium, J. Ind. Environ. Chem., 2017, 1, no. 1, 15-21.

41. N.O. Eddy, P. Ameh, C.E. Gimba and E.E. Ebenso, GCMS Studies On Anogessus Leocarpus (Al) Gum and Their Corrosion Inhibition Potential for Mild Steel in $0.1 \mathrm{M}$ HCl, Int. J. Electrochem. Sci., 2011, 6, 5815-5829.

42. T.H. Ha, J.-H. Bae, Y.-C. Ha, H.G. Lee, K.-W. Park and D.-K. Kim, Trans. SAEST, 2004, 39, 1.

43. M. Mobin, M. Parveen and M.Z.A. Rafiquee, J. Mater. Eng. Perform., 2012, 1. 
44. P. Prabhakar, S. Shanmugapriya and S. Rajendran, Corrosion resistance property of neem extract in reinforced concrete, Int. J. Anal. Exp. Modal Anal., 2019, 11, no. 8, 275280. doi: 18.0002.IJAEMA.2019.V11I8.208301.2912

45. P. Shanthy, J.A. Thangakani, S. Karthika, S.C. Joycee, S. Rajendran and J. Jeyasundari, Corrosion inhibition by an aqueous extract of Ervatamia divaricate, Int. J. Corros. Scale Inhib., 2021, 10, no. 1, 331-348. doi: 10.17675/2305-6894-2021-10-1-19

46. S. Rajendran, R. Srinivasan, R. Dorothy, T. Umasankareswari and A. Al-Hashem, Green solution to corrosion problems-at a glance, Int. J. Corros. Scale Inhib., 2019, 8, no. 3, 437-479. doi: $10.17675 / 2305-6894-2019-8-3-1$

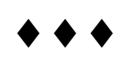

